
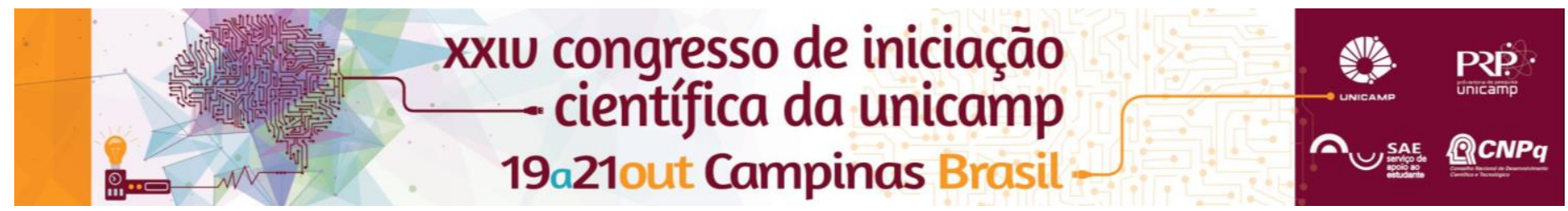

\title{
O conhecimento geográfico na Idade Média. As transformações metodológicas e epistemológicas sobre a natureza nos séculos XII e XIII e seu papel na concepção de Geografia.
}

\section{Gisele C. Cavalcante*}

\begin{abstract}
Resumo
Entre os séculos XII e XIII, a Europa se encontrava em uma maior estabilidade político-econômica do que nos séculos anteriores e com o fim dos ataques bárbaros, a sensação de segurança era mais presente. Com essa tranquilidade, grandes transformações sociais e intelectuais entraram em curso, fazendo com que novas técnicas de cultivo de terras fossem desenvolvidas e equipamentos fossem aprimorados, resultando no aperfeiçoamento da produção medieval. Esses fatores contribuíram para a alteração do entendimento que o homem medievo possuía acerca espaço, ou seja, da sua concepção geográfica.
\end{abstract}

Palavras-chave:

Geografia, Idade Média, Metodologia Científica.

\section{Introdução}

Este trabalho visa apresentar as transformações espaciais e de mentalidade que ocorreram nos séculos XII e XII da Idade Média, abordando com maior enfoque, a maneira como a sociedade medieval interveio na natureza com a finalidade de satisfazer suas necessidades e atender suas demandas, a importância do campo para o desenvolvimento das cidades e a relação do comércio com a indústria.

A ideia também é salientar a cidade medieval como o palco para a prosperidade intelectual, científica e filosófica.

\section{Resultados e Discussão}

A última invasão bárbara (vikins), no século $\mathrm{XI}$, fez com que a Europa emanasse uma "nova energia". Diante disso, inicia-se a largada para instauração de novas instituições e inauguração das novas técnicas e tecnologias.

Segundo Gimpel (1977), entre os séculos XII e XIII, as alterações no sistema de culturas e a introdução de novas técnicas de cultivo fizeram com que houvesse o aumento da oferta de alimentos.

Duas das principais transformações que campo apresentou foram a substituição do boi pelo cavalo e a troca da azenha pelo moinho de vento. O boi era capaz de percorrer maior caminho em menos tempo e sua alimentação é mais barata e a instalação e manutenção do moinho de vento tem o custo mais baixo em detrimento a azenha

A maior produção de alimentos fez crescer a circulação de comerciantes e mercadores nos burgos fortificados. Os movimentos de troca que antes eram intermitentes passaram a ser constantes, e é neste contexto que o comércio nos burgos se estabelece de forma fixa e não itinerante (PIRENNE, 1964).

Além de ser o lugar da troca, a cidade medieval fica conhecida por abrigar as primeiras universidades. Elas foram um importante instrumento de institucionalização do conhecimento e também o local onde o conhecimento teórico foi associado à empiria (GRANT, 2002).

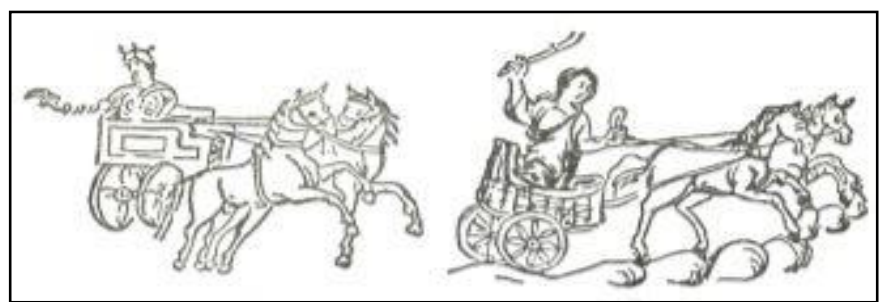

Figura 1: Evolução da aparelhagem para preparar a terra. Fonte: LOPEZ, R. S., p. 56 (1976)

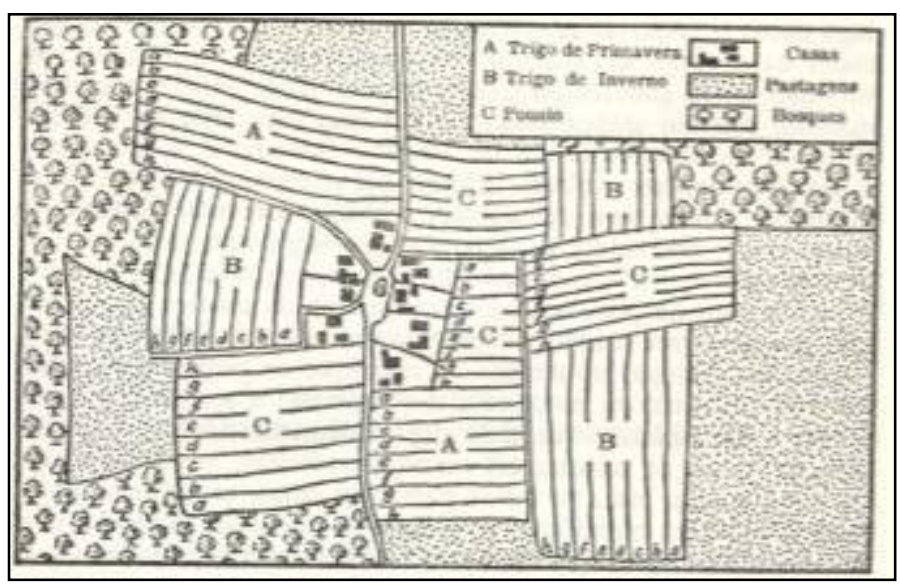

Figura 2: Cultivo característico de uma senhoria medieval. Fonte: LOPEZ, R. S., p. 56 (1976)

\section{Conclusão}

Os séculos XII e XIII da Idade Média foram momentos na História com uma efervescência social, cultural, técnica e intelectual importante. As noções de espaços se modificaram e o emprego dos conhecimentos possibilitou alterações no modo de pensar e entender o meio. Tais transformações serviram de suporte para a Modernidade.

GIMPEL, J. A revolução industrial da Idade Média. Édition du Seuil, 1975. GRANT, Edward. Os fundamentos da Ciência Natural na Idade Média. Editora Porto Alegre, 2002.

LOPEZ, R. S. A revolução comercial na Idade Média, 950-1350. Editorial Presença, 1976. 